\title{
POMENOPAUZINIS KRAUJAVIMAS IŠ GIMDOS: KLASIFIKACIJA, PRIEŽASTYS, DIAGNOSTIKA, GYDYMAS
}

\author{
Agnẻ Skvarnavičiūtė \\ Lietuvos sveikatos mokslu universiteto Medicinos fakultetas
}

Raktažodžiai: pomenopauzinis kraujavimas iš gimdos, nenormalus kraujavimas, PALM-COEIN.

\section{Santrauka}

Pomenopauzinis kraujavimas - tai kraujavimas iš gimdos, atsirandantis praejjus mažiausiai vieneriems metams nuo menopauzès pradžios. Tai dažna medicininè problema, tiesiogiai veikianti moteru gyvenimo kokybę, sveikatos priežiūros išteklių panaudojimą ir išlaidas. Kraujavimas po menopauzès yra viena iš dažniausių priežasčių, dèl kurių moterys kreipiasi ị gydytojus akušerius ginekologus.

Pomenopauzinio kraujavimo iš gimdos gydymas priklauso nuo diagnozuotos kraujavimo priežasties ir turètu būti pritaikytas individualiai, atsižvelgiant ị pacientès sveikatos būklę, tikslus. Pomenopauzinis kraujavimas gali būti pirmasis endometriumo véžio požymis, todèl klinikinis kraujavimo po menopauzės tyrimas reikalingas greito ir efektyvaus ịvertinimo, kad būtų diagnozuota ir gydoma endometriumo karcinoma ar endometriumo hiperplazija.

Tyrimo tikslas - išsiaiškinti pomenopauzinio kraujavimo iš gimdos klasifikaciją, priežastis, diagnostiką ir gydymą. Metodika. Literatūra buvo rinkta naudojant Pubmed duomenų bazę.

Išvados. Kraujavimas pomenopauziniu laikotarpiu yra dažna kreipimosi i gydytojus ginekologus priežastis. Kraujavimas iš gimdos turètų būti ịvertintas remiantis PALM - COEIN klasifikacija. Šiuo metu histeroskopija su atliekamomis biopsijomis yra auksinis standartas diagnozuoti endometriumo anomalijas. Gydymas priklauso nuo kraujavimo etiologijos, taikomas individualiai, atsižvelgiant ị pacientès sveikatos būklę, tikslus.

\section{İvadas}

Natūrali menopauzè apibrěžiama kaip visiška mėnesinių pabaiga, nustatoma moterims retrospektyviai po 12 ménesių amenorejos [1]. Vidutinis menopauzès amžius yra penkias- dešimt vieneri metai. Menopauzè nustatoma, kai kiaušidès nustoja gaminti estrogeną, nebevyksta ovuliacija [2]. Nenormalus kraujavimas iš gimdos yra dažnas ginekologinis skundas, kuris sudaro trečdali ambulatorinių apsilankymų pas ginekologus ir daugiau nei 70 proc. visu ginekologų konsultacijų perimenopauzès ir pomenopauzès metais [3]. Pomenopauzinis kraujavimas (PK) - tai kraujavimas iš gimdos, atsirandantis praèjus mažiausiai vieneriems metams nuo menopauzès pradžios [4]. Be to, kraujavimas iš makšties yra pagrindinis moterų po menopauzès (daugiau kaip 90 proc. atvejų) endometriumo vėžio požymis [3].

Tyrimo tikslas - išsiaiškinti pomenopauzinio kraujavimo iš gimdos klasifikaciją, priežastis, diagnostiką ir gydymą.

\section{Tyrimo medžiaga ir metodai}

Literatūra šiai apžvalgai buvo rinkta naudojant Pubmed duomenų bazę. Literatūros paieška buvo atliekama naudojant parinktus raktinius žodžius, išnagrinèta 20 publikacijų, susijusių su pomenopauziniu kraujavimu.

\section{Tyrimo rezultatai}

Nenormalaus kraujavimo iš gimdos klasifikacija ir priežastys. Tarptautinè akušerijos ir ginekologijos federacija (FIGO) pristatè nenormalaus kraujavimo iš gimdos klasifikavimo sistemą, kurią 2012 m. patvirtino Amerikos akušerių ginekologų kongresas, siekdamas suvienodinti patologinio kraujavimo iš gimdos terminiją. Ši sistema, žinoma akronimu PALM-COEIN, pagal įtariamą etiologiją klasifikuoja nenormalų kraujavimą iš gimdos:
P - polipai;
A - adenomiozé;
L - lejomiomos;
M - piktybiniai procesai ir hiperplazija;
C - koagulopatijos (angl. coagulopathy);
O - ovuliacinès disfunkcijos;
E - endometriumo patologijos;
I - jatrogeninès ir kitos (angl. iatrogenic);
$\mathbf{N}$ - nežinomos priežastys ar dar neklasifikuojamos. 
PALM -COEIN PALM dalis apima struktūrines nenormalaus kraujavimo iš gimdos priežastis. COEIN akronimas reiškia nestruktūrines, hormonines ar sistemines nenormalaus kraujavimo iš gimdos priežastis [3].

Daugumai moterų kraujavimas iš gimdos prasideda dèl makšties ar endometriumo atrofinių pokyčių [5]. Nors daugeliu atvejų nenormalus kraujavimas iš gimdos nesusijęs su piktybiniu ar hiperplaziniu pažeidimu, yra žinoma, kad po menopauzès esant nenormaliam kraujavimui iš gimdos, endometriumo vėžio rizika yra 10 proc. [6], o pasaulyje sergamumas endometriumo vėžiu didèja [7].

Pomenopauzinio kraujavimo diagnostika. Kraujavimas iš gimdos turètų būti diferencijuojamas nuo kito ginekologinès (vulvos, makšties) ir ne ginekologinès (tarpvietès srities, šlaplès) kilmès kraujavimo [4]. Pomenopauzinį kraujavimą iš makšties gali sukelti ir gimdos kaklelio véžys, todèl turètų būti atliekamas ir gimdos kaklelio citologinis tyrimas [8].

Iš anamnezès svarbu išsiaiškinti dèl adjuvantinio krūties karcinomos tamoksifenu gydymo, kadangi tamoksifenas ir kiti selektyvūs estrogeno receptorių moduliatoriai (SERM) didina endometriumo neoplazijos tikimybę. Tokiais atvejais turètų būti imami endometriumo mèginiai ir tiriami histologiškai, jei nęmmanoma - atliekamos histeroskopijos ir gimdos kiuretažas [9].

Daugelyje rekomendacijų endometriumo storio matavimas transvaginalinio ultragarso metu naudojamas kaip pirmasis diagnostikos žingsnis, norint nustatyti, maža ar didelè pacientès rizika susirgti endometriumo véžiu [10]. Jei ultragarsinio tyrimo metu matomas $4 \mathrm{~mm}$ ar plonesnis endometriumas, tai reiškia 99 proc. neigiamą endometriumo véžio prognostinę vertę [11]. Nustačius storesnị endometriumą ar esant nuolatiniam (pasikartojančiam) pomenopauziniam kraujavimui, reikalingas tolesnis tyrimas. Galima atlikti sonohisterografiją, kuri apima ịprastinio fiziologinio tirpalo ị gimdos ertmę infuziją, leidžiančią geriau ịvertinti gimdos pažeidimus. Nustatant endometriumo patologiją pacientèms, besiskundžiančioms pomenopauziniu kraujavimu, sonohisterografijos jautrumas buvo 86,5 proc., specifiškumas - 91,1 procento [12]. Vis dèlto vienas iš tinkamiausių metodų tirti gimdos ertmę moterims, esant endometriumo sustorejjimui, yra minimaliai invazinè procedūra - histeroskopija [13]. Vertinama, kad tai saugi, jautri diagnostiné procedūra, kurios komplikacijų rizika $<1$ procento [14]. Vis dažniau pasirenkami mažiau invazyvūs, inovatyvesni metodai, pavyzdžiui, endometriumo biopsija pipele. Taip paimtos biopsinès medžiagos histologinio ištyrimo tikslumas diagnozuojant endometriumo vėži po menopauzès - 99,6 proc., diagnozuojant hiperplaziją - 81 procentas [15]. Šiuo metu auksinis standartas diagnozuoti endometriumo anomalijas yra histeroskopija su atliekamomis biopsijomis [16].
Pomenopauzinio kraujavimo gydymo metodai. Nustatyta etiologija lemia kraujavimo po menopauzès valdymą ir gydymą. Gydymas turètų būti pritaikytas individualiai, atsižvelgiant ị pacientès sveikatos būklę, tikslus. Sprendžiant dèl gydymo, pirmiausia turètų būti svarstomos mažiausiai invazyvios galimybès, o tik vèliau taikomos invazyvios procedūros [17].

Nustačius polipą, dažniausiai galvojama apie gerybini darinị, tačiau apie 5 proc. jų gali hiperplazuoti ir išsivystyti ị piktybinį naviką, todèl reikia rinktis stebejimą arba histeroskopinị polipo pašalinimą [1]. Adenomiozè gali būti gydoma endometriumo abliacija, jei adenomiozès gylis mažesnis nei $2,5 \mathrm{~mm}$, o jei invazija gilesnè, rekomenduojama gimdos pašalinimo operacija [14]. Miomos gali būti gydomos taikant gimdos arterijos embolizaciją arba pašalinamos chirurgiškai [18]. Endometriumo intraepitelinè neoplazija gali būti gydoma geriamaisiais progestinais, endometriumo stebèsena, endometriumo piktybinius navikus geriausiai gydyti histerektomija [19]. Dėl koagulopatijų sukelto kraujavimo gali būti naudingi nesteroidiniai vaistai nuo uždegimo (NVNU), progestino terapija (peroraliné, ị raumenis arba po oda) arba traneksamo rūgštis. Taip pat gali būti taikoma endometriumo abliacija ar gimdos pašalinimo operacija [20].

\section{Apibendrinimas}

Kraujavimas pomenopauziniu laikotarpiu yra dažna kreipimosi i gydytojus ginekologus priežastis. Kraujavimas iš gimdos turètų būti ịvertintas remiantis PALM - COEIN klasifikacija. Šiuo metu histeroskopija su atliekamomis biopsijomis yra auksinis standartas diagnozuoti endometriumo anomalijas. Gydymas priklauso nuo kraujavimo etiologijos, taikomas individualiai, atsižvelgiant ị pacientès sveikatos būklę, tikslus.

\section{Išvados}

1. Kraujavimas pomenopauziniu laikotarpiu yra dažna moterų kreipimosi ị gydytojus ginekologus priežastis.

2. Kraujavimas iš gimdos turetų būti įvertintas remiantis PALM - COEIN klasifikacija.

3. Šiuo metu histeroskopija su atliekamomis biopsijomis yra auksinis standartas diagnozuoti endometriumo anomalijas.

4. Tolimesnis gydymas priklauso nuo kraujavimo etiologijos. Gydymas turètų būti pritaikytas individualiai, atsižvelgiant ị pacientès sveikatos būklę, tikslus.

\section{Literatūra}

1. Takahashi TA, Johnson KM. Menopause. Med Clin North Am 2015; 521-34. 
2. Sung S, Abramovitz A. Postmenopausal bleeding. StatPearls 2021.

3. Khafaga A, Goldstein SR. Abnormal uterine bleeding. Obstet Gynecol Clin North Am 2019;46(4):595-605.

4. Munro MG. Investigation of women with postmenopausal uterine bleeding: clinical practice recommendations. Perm J 2014;18(1):55-70.

5. Goldstein SR. Appropriate evaluation of postmenopausal bleeding. Menopause 2018;25(12):1476-8.

6. Giannella L, Cerami LB, Setti T, Bergamini E, Boselli F. Prediction of endometrial hyperplasia and cancer among premenopausal women with abnormal uterine bleeding. Biomed Res Int 2019;2019. https://doi.org/10.1155/2019/8598152

7. Clarke MA, Long BJ, Del Mar Morillo A, Arbyn M, BakkumGamez JN, Wentzensen N. Association of endometrial cancer risk with postmenopausal bleeding in women a systematic review and meta-analysis. JAMA Intern Med 2018;178:1201-8. https://doi.org/10.1001/jamainternmed.2018.2820

8. Sindhuri R, Dongre AR. Postmenopausal bleeding among rural women in Tamil Nadu, India: mixed methods study. Indian J Community Med 2018;43:288-93.

9. Munro MG. Investigation of women with postmenopausal uterine bleeding: clinical practice recommendations. Perm J 2014; 18:55-70.

https://doi.org/10.7812/TPP/13-072

10. Van Hanegem N, Prins MMC, Bongers MY, Opmeer BC, Sahota DS, Mol BWJ, et al. The accuracy of endometrial sampling in women with postmenopausal bleeding: a systematic review and meta-analysis. Eur J Obstet Gynecol Reprod Biol 2016;197:147-55.

https://doi.org/10.1016/j.ejogrb.2015.12.008

11. ACOG Committee Opinion No. 734: the role of transvaginal ultrasonography in evaluating the endometrium of women with postmenopausal bleeding. Obstet Gynecol 2018;131(5):e124-9. https://doi.org/10.1097/AOG.0000000000002631

12. Carugno J. Clinical management of vaginal bleeding in postmenopausal women. Climacteric 2020;23(4):343-9.

https://doi.org/10.1080/13697137.2020.1739642

13. Omar AA, Seham A, Al-Kharabsheh AM, Alshara E, Sindiani AM, Hamdan O, et al. Clinical and sonographic evaluation of postmenopausal bleeding (PMB) followed by diagnostic and/ or therapeutic hysteroscopy and guided biopsy in Jordanian hospitals. Medicina (Kaunas) 2020; 56(4):147.

https://doi.org/10.3390/medicina56040147

14. Jansen FW, Vredevoogd CB, Van Ulzen K, Hermans J, Trimbos JB, Trimbos-Kemper TCM. Complications of hysteroscopy: a prospective, multicenter study. Obstet Gynecol 2000;96:266-70.

https://doi.org/10.1097/00006250-200008000-00021

15. van Hanegem N, Breijer M, Slockers S, Zafarmand M, Geomini
P, Catshoek R, et al. Diagnostic workup for postmenopausal bleeding: a randomised controlled trial. BJOG An Int J Obstet Gynaecol 2017;124:231-40.

https://doi.org/10.1111/1471-0528.14126

16. Brown A, Shenker N. Experiences of breastfeeding during COVID-19: lessons for future practical and emotional support. Matern Child Nutr 2021;17. https://doi.org/10.1111/mcn.13088

17. Oberman E, Rodriguez-Triana V. Abnormal uterine bleeding: treatment options. Clin Obstet Gynecol 2018;61:72-5. https://doi.org/10.1097/GRF.0000000000000340

18. Albers JR, Hull SK, Wesley RM. Abnormal uterine bleeding. Am Fam Physicians 2004; 69(8):1915-26.

19. Vetter MH, Smith B, Benedict J, Hade EM, Bixel K, Copeland LJ, et al. Preoperative predictors of endometrial cancer at time of hysterectomy for endometrial intraepithelial neoplasia or complex atypical hyperplasia. Am J Obstet Gynecol. Mosby Inc. 2020; 60.e1-60.e7.

https://doi.org/10.1016/j.ajog.2019.08.002

20. Marnach ML, Laughlin-Tommaso SK. Evaluation and management of abnormal uterine bleeding. Mayo Clin Proc Elsevier Ltd 2019:326-35.

https://doi.org/10.1016/j.mayocp.2018.12.012

\section{POSTMENOPAUSAL UTERINE BLEEDING: CLASSIFICATION, CAUSES, DIAGNOSIS, TREATMENT}

A. Skvarnavičiūtè

Keywords: postmenopausal uterine bleeding, abnormal bleeding, PALM-COEIN.

Summary

Postmenopausal bleeding is bleeding from the uterus that occurs at least one year after the beginning of menopause. It is a common medical issue that has direct consequences on women's quality of life, healthcare resources and expenses. Postmenopausal bleeding is one of the most common problems that women come to obstetricians-gynecologists for.

Postmenopausal uterine bleeding treatment depends on the diagnosed cause of the bleeding and should be chosen individually based on the patient's health and goals. Postmenopausal bleeding may be the first symptom of endometrial cancer, therefore a clinical examination of postmenopausal bleeding must have a fast and effective conclusion, so that in the case of endometrial cancer, the endometrial carcinoma or hyperplasia can be quickly diagnosed and treated. Cases of postmenopausal bleeding should therefore be taken seriously and cannot be ignored, even if they may appear minor.

Correspondence to: agne.skvarnaviciute@gmail.com

Gauta 2021-04-12 